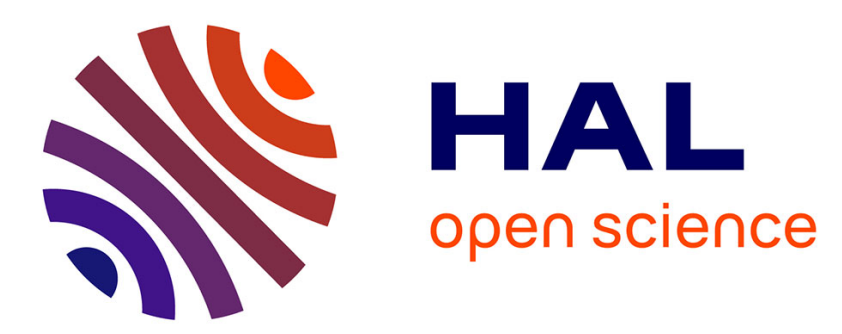

\title{
Defining context-specific scenarios to design vegetated buffer zones that limit pesticide transfer via surface runoff
}

\author{
Nadia Carluer, Claire Lauvernet, Dominikus Noll, R. Muñoz Carpena
}

\section{To cite this version:}

Nadia Carluer, Claire Lauvernet, Dominikus Noll, R. Muñoz Carpena. Defining context-specific scenarios to design vegetated buffer zones that limit pesticide transfer via surface runoff. Science of the Total Environment, 2017, 575, pp.701-712. 10.1016/j.scitotenv.2016.09.105 . hal-02605064

\section{HAL Id: hal-02605064 https://hal.inrae.fr/hal-02605064}

Submitted on 16 May 2020

HAL is a multi-disciplinary open access archive for the deposit and dissemination of scientific research documents, whether they are published or not. The documents may come from teaching and research institutions in France or abroad, or from public or private research centers.
L'archive ouverte pluridisciplinaire $\mathbf{H A L}$, est destinée au dépôt et à la diffusion de documents scientifiques de niveau recherche, publiés ou non, émanant des établissements d'enseignement et de recherche français ou étrangers, des laboratoires publics ou privés. 
1 Defining context-specific scenarios to design vegetated buffer zones 2 that limit pesticide transfer via surface runoff.

3 N. Carluer $^{1}$, C. Lauvernet ${ }^{1}$, D. Noll ${ }^{1}$, R. Munoz-Carpena ${ }^{2}$

4 [1]\{Irstea, UR MALY, centre de Lyon-Villeurbanne, 5 rue de la Doua-CS 70077, F-69626 Villeurbanne cedex, 5 France\}

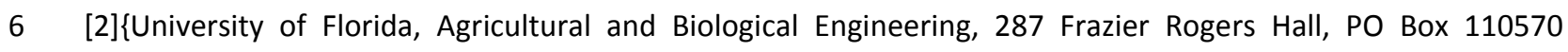
Gainesville, FL 32611-0570, USA\} Correspondence to N. Carluer: nadia.carluer@irstea.fr

9

Keywords: vegetative filter strip; buffer zone modelling; process-based model; VFS sizing; shallow water table; watershed

\section{Introduction}

Diffuse pollution (nitrates, phosphates, suspended matter, pesticides, and metals) has a significant effect on water resources. These contaminants are likely to harm the ecological quality of waterways and to compromise capacities to meet the "good ecological status" ambitious target set in 2015 by the WFD (Water Framework Directive). They may also compromise the drinking water supplies of populations and necessitate the use of expensive treatments to reach drinking water standards. For plant protection products, it is necessary to act at several levels to minimize non-point pollution: limiting their use and preventing and limiting their transfer from agricultural fields to water resources. Regarding this solution, vegetative buffer zones (grass strips, wood, riparian forests, etc.) are considered to be the most efficient buffers for pollutants transported mainly through surface runoff and sediment, by enhancing the retention and degradation of active substances (eg Poletika et al., 2009; Reichenberger et al., 2007). However, several factors related to topographical features and agricultural practices can affect vegetative filter zones (i.e., vegetative filter strips (VFSs)), determining their performance and limiting their effectiveness: to be efficient, they must be correctly designed in consideration of their positioning (Tomer et al., 2008), type, and size (Daniels and Gilliam 1996; Dosskey et al. 2002, 2011). Furthermore, fixed VFS widths do not prevent water, sediment and pesticide transfer, as surface runoff is never spatially uniform on a field given heterogeneities of topographical and soil characteristics (Beven et al, 1998). For VFS sizing, a field diagnosis must be performed, ideally at the watershed scale, to identify the main potential sources and pathways of contamination. It should bebased on soil characteristics, crops, cultural practices, topographical features and observed runoff pathways. It is then possible to determine which mitigation solutions to adopt and to select appropriate VFS sizes and positions when this choice is relevant (Bernard et al, 2014. in French). The first solution for VFS sizing involves using field expert knowledge or recommendations from national or local institutions, functioning in a given context (e.g., CORPEN/Cemagref in France and the USDA in the US). Yet conditions that influence pollutant retention through a buffer (e.g., soil, slope, and hydrology) can differ substantially from one location to another (Lowrance et al., 1997, Dosskey 
Author-produced version of the article published in Science of The Total Environment, Volume 575, 1 January 2017, Pages 701-712 The original publication is available at http://www.sciencedirect.com/ http://dx.doi.org/10.1016/j.scitotenv.2016.09.105 This manuscript version is made available under the CC-BY-NC-ND 4.0 license

2006), and pollutants do not behave similarly in buffer soils, as a function of their physico-chemical properties. This is why simple laws cannot represent the diversity of soil, agronomic, climatic and chemical scenarios. More deterministic methods can then be used (e.g., abacus or "decision rules" developed for some specific watersheds) via physical modelling depending on soil survey attributes (mainly slope, soil and rainfall factors) (e.g., Dosskey et al., 2006). A physical approach to sizing vegetated buffers involves directly applying a physical model that is specifically parameterized to a given local context. The Vegetative Filter Strip MODel VFSMOD (Munoz-Carpena et al, 1999) is a vegetative filter strip physically based model that can be applied directly as a VFS sizing tool either for one given VFS location (Dosskey et al., 2006, 2008, 2011) or at a larger scale by coupling it to a watershed model (White and Arnold, 2009) or to GIS tools (e.g., Park et al. 2013). This tool, however, must be properly parameterized to determine local characteristics of flow entering a filter as well as rainfall typical events, initial conditions, soil characteristics, and buffer properties. The method proposed by Dosskey et al $(2008,2011)$, which involves using soil surveys to determine widths of filter strips based on laws of VFSMOD simulations, is currently the most appropriate approach available, as it is physically based but also simple enough to be used in an operational context. However, the method can be applied and tested for sediment reduction only and not to examine pesticides, and the authors note several limitations to their method: the Green-Ampt solution used in the VFSMOD does not allow one to examine conditions wherein a VFS is bounded by a shallow (perched) water table. This boundary condition can severely limit VFS infiltration capacities by causing runoff by saturation. This is an important restriction, as VFSs can be located in an area where a shallow impermeable soil layer can form perched water tables and also because VFSs are often located along river networks, increasing the probability of shallow river connection formation (Reichenberger et al., 2007; Lacas et al., 2012) The latest version of VFSMOD (Munoz-Carpena et al., submitted) simulates infiltration under shallow water table conditions. Other limitations of the (Dosskey et al 2008, 2011) method concern infiltrated pollutants, for which behaviour in soil is not represented by VFSMOD. However, a model representing pollutant transport through soil would need to represent lateral transfer and chemical reactions, adding a large set of input parameters. It would thus likely lose operational properties that allow nonmodellers to use this method. In this study, we propose a new method that improves modelling scenarios and their applicability in the field though physical basis. Scenarios take into account initial states of humidity and water table effects on VFS infiltration. The proposed method is then based on (i) the quantification of water flows produced by the contributing area and (ii) on VFS capacities to infiltrate incoming flows.

We first briefly review the main physical processes that occur in a VFS to properly apply the method. The method then is presented and applied to a test catchment in north-western France. Our construction of nomograms from a large sample of simulated scenarios is then described as a method to be used by nonmodellers.

\section{Physical processes of a vegetative buffer zone}

The contributive area of a buffer zone is defined as the part of a watershed where flows entering the buffer zone are generated. Incoming surface runoff on a buffer zone is very sensitive to contributive area extension and characteristics. Consequently, it is important that the sizing step occurs after diagnosis at the watershed 
Author-produced version of the article published in Science of The Total Environment, Volume 575, 1 January 2017, Pages 701-712 The original publication is available at http://www.sciencedirect.com/ http://dx.doi.org/10.1016/j.scitotenv.2016.09.105 This manuscript version is made available under the CC-BY-NC-ND 4.0 license

level to ensure that the nature of the buffer zone and its positioning are relevant in consideration of environmental conditions. Ideally, buffer zone implementation should occur at the catchment scale for optimal sizing.

\section{I.1 Water flow components within a buffer zone}

Water flows into and on the ground through the following three main pathways: infiltration and deep percolation, shallow subsurface lateral flow, and surface runoff. This article focuses on dry buffer zones, which are mainly of relevance to the latter mode of circulation. We distinguish here between "dry" buffer zones where soil surfaces are not supposed to be durably ponded (grass strips, wood, riparian forests, etc.) and "wet" buffer zones where major dissipating processes are linked to wet conditions (artificial wetlands). Surface runoff can be generated when rainfall rates exceed soil surface hydraulic conductivity so that excess water does not infiltrate, and generate surface flow (Hortonian runoff) or when an entire soil profile becomes saturated with water (before or during an event) so that all incoming water contributes to surface runoff (runoff on a saturated surface). These two main forms of runoff, and Hortonian runoff in particular, can be erosive and can transport fine particles detached from the ground through raindrops or flow. Nevertheless, erosion is not systematic when runoff occurs, and especially when simplified cultural practices are used and when soil is rich in clay or organic matter.

\section{I.2 Key drivers of vegetative buffer strip efficiency}

Three features allow buffers to reduce runoff and retain pesticides (see Figure 1). VFS soil permeability is higher than that of cultivated plot permeability due to the significant root density of grass cover of the former (the existence of a root mat, i.e., a dense layer rich in fine living and dead roots, linked to the presence of permanent vegetation in the upper ten centimetre layer of soil). This high infiltration capacity usually reduces incoming water flows significantly. A second property is high roughness due to the density of the aerial component of vegetation. This slows runoff on one hand while settling eroded particles and molecules adsorbed on their surface on the other. Finally, high organic carbon content levels increase the adsorption capacity of the buffer zone relative to that of a cultivated soil. Regarding degradation, it seems that although it is rich in organic matter and promotes microbial activity, buffer zone soil does not generally contain a significant number of microorganisms adapted to degrade specific pesticides entering an area. As a consequence, microbial activity remains nonspecific (Madrigal-Monarrez, 2004, In French); the microbial community can however be adapted to degrade specific pesticides in cases of repeated exposure (DeversLamrani et al., 2014).

Dry buffer mitigation efficiency levels are dependent on their width (dimension in the direction of flow) and on the following ratio in particular: contributing area / buffer zone area (Arora et al., 1996). The effective length (perpendicular to the flow direction) also influences buffer efficiency, and especially in cases of concentrated flow. Indeed, both field and modelling studies have confirmed that constant-width filter strips are less effective at trapping sediment, nitrogen, phosphorus and pesticides when concentrated flow occurs than when flow is uniform (Dosskey et al., 2011; Fox et al., 2010). The VFS infiltration capacity can in this case be exceeded, as only part of the surface contributes to infiltration. As a consequence, the width needed to infiltrate incoming 
Author-produced version of the article published in Science of The Total Environment, Volume 575, 1 January 2017, Pages 701-712 The original publication is available at http://www.sciencedirect.com/ http://dx.doi.org/10.1016/j.scitotenv.2016.09.105 This manuscript version is made available under the CC-BY-NC-ND 4.0 license

runoff may be much higher. The calculated design method is then relevant only when concentration phenomena are prevented or mitigated (e.g., using additional upslope elements as fagots, hedges or embankments).

\section{Design method}

\section{II.1 Framework}

The infiltration of water and pesticides is often the main process shaping pesticide transport reduction (Lacas, Voltz et al. 2005, Reichenberger, Bach et al. 2007). On top of this, pesticide behaviour in and on soils varies depending on active substance physico-chemical characteristics, and in particular: Koc, reflecting their capacities to be sorbed on soil aggregates and DT50, reflecting their capacities to be quickly degraded. Yet, VFSs are semi-permanent devices and their sizes may not change from one year to another. They should thus be efficient for a broad range of pesticides owing to their physico-chemical characteristics.

As a consequence, the method presented in this paper only considers surface runoff reduction. We propose that pesticide exportation attenuation should be at least equal to surface water flow reduction. This hypothesis is based on the finding that VFSMOD (the model used to simulate VFS behaviour -see below-), simulations always leads to sediment retention higher than surface runoff attenuation. As a consequence, for a given surface runoff attenuation level, attenuation will be the same for pesticides in solution or for pesticides sorbed on fine sediments, which will infiltrate along with water, and will at least be the same for pesticides sorbed on sediments settled on the upslope boundary of a VFS. This overall level of efficiency is increased by pesticide fraction that is sorbed on the VFS soil surface. As a consequence, this hypothesis will at worse lead to an underestimation of buffer zone effectiveness, as it does not take into account the deposition of sediments along the upstream boundary of a buffer zone or the adsorption of active substances on the surface of a buffer zone. However, mainly coarse sediments settle upstream from buffer zones while pesticides are mainly adsorbed on fine sediment. Though under very erosive conditions, the previous assumption may be exaggerated.

The simulation method for deriving buffer sizes involves two steps (see the flowchart in Figure 2). First, surface runoff traveling from a contributive area to a buffer zone is assessed for a variety of representative rainfall events considering climatic characteristics of the geographic region examined and the contributive area's topographical and crop features. Second, buffer zone efficiency is evaluated in consideration of implementation area features of each surface runoff scenario and for a range of sizes using a numerical model that simulates water flows in a vegetative buffer zone (VFSMOD). Finally, an optimal size is derived for the chosen desired efficiency rate.

\section{II.2 Assessment of surface runoff generated on contributive areas}

The objective of this first step is to cover a range of realistic conditions on surface runoff entering a VFS. This involves considering several scenarios (in terms of soil, agriculture, and climate) to explore variety of events that can occur in a given area. Each scenario is defined by a season, crop (which influences soil surface 
Author-produced version of the article published in Science of The Total Environment, Volume 575, 1 January 2017, Pages 701-712 The original publication is available at http://www.sciencedirect.com/ http://dx.doi.org/10.1016/j.scitotenv.2016.09.105 This manuscript version is made available under the CC-BY-NC-ND 4.0 license

characteristics and pesticide application periods), and typical rainfall event. A corresponding surface runoff hydrograph is then derived via the Curve Number method (USDA-SCS 1972). A return period of one year (precipitation event occurring once per season on average) is considered to define rainfall events so that the VFS is designed for frequent runoff events.

\section{II.2.1 Rainfall event characterization}

Through a long term rainfall data analysis, Intensity-Duration-Frequency rainfall data were derived for $4 * 4 \mathrm{~km}$ square zones covering the French territory (Aubert et al., 2014). Although this method is usually used to assess the probability for extreme events, we focused on frequent events (return period of one year). VFSs are here designed to mitigate pesticide transfer instead of flooding. From this point of view, extreme events are linked to the occurrence of surface runoff events shortly after pesticide application and not necessarily to the occurrence of severe runoff events. Two seasons are considered in the rainfall analysis: winter (November to April) and summer (May to October). Rainfall regimes can differ significantly in the winter and summer. As a result, rainfall volumes occurring once a year on average for $1 \mathrm{~h}$ to $48 \mathrm{~h}$ are available for France based on a 4$\mathrm{km}$ grid for the winter and summer. Such a method, which prevents the designer from being subjective when choosing a "representative rainfall event" for an area, could be applied to study other countries provided data are available. For each location in France, season and rainfall duration, a hyetograph can be generated for an intensive or moderate event (see for example Figure 3 on the Fontaine du Theil catchment in northern France, which is described in following section).

\section{II.2.2 Incoming runoff event assessment}

One of the most influential characteristics of a contributive area is its capacity to generate surface runoff: highly permeable soils facilitate water infiltration while less permeable and capping soils turn large proportions of incoming rainfall into surface runoff. Much runoff is also produced when the soil top layer is permeable but situated above a shallow groundwater table (e.g., less than $1 \mathrm{~m}$ below the soil surface) or when an impermeable soil layer exists at a shallow depth (e.g., a plough layer) and inhibits water infiltration into deeper subsoil.

For a rainfall event, the resulting surface runoff hydrogram is determined via the Curve number method (USDASCS 1972). The Curve Number is dependent on the soil hydrological class and crop considered, on hydrological conditions and on the soil humidity status (i.e., soil humidity at the beginning of the rainfall event). As it significantly influences generated surface runoff and is very sensitive, it must be selected carefully and, when possible, validated with observed data. The USDA-SRC (1972) considers 4 classes of soil with typical characteristics summarized in Table 7, Appendix 1 (class A highly permeable to class $D$ hardly permeable). Impermeable layers or a higher water table can influence soil water infiltration capacities and can change a soil hydrological group, based on its texture only. Hydrological conditions are dependent on soil occupation features: the more a crop covers the soil, the more these conditions are considered to be favourable. Thus, this parameter evolves over time. 
Author-produced version of the article published in Science of The Total Environment, Volume 575, 1 January 2017, Pages 701-712 http://dx.doi.org/10.1016/j.scitotenv.2016.09.105 This manuscript version is made available under the CC-BY-NC-ND 4.0 license

Nominal values are associated with average initial humidity conditions $\left(\mathrm{CN}_{\| 1}\right)$, but it is possible to calculate a Curve Number $\mathrm{CN}_{1}$ for dry humidity conditions and a Curve Number $\mathrm{CN}_{\mathrm{III}}$ representative of wet initial humidity conditions using Chow et al. (1988) method as follows:

Equation 1: $C N_{I}=4.2 * \frac{C N_{I I}}{10-0.058 * C N_{I I}}$ and $C N_{I I I}=23 * \frac{C N_{I I}}{10+0.13 * C N_{I I}}$

Finally, the incoming hydrogram is defined based on the contributive area average slope, surface, and longest hydraulic path using a GIS tool. However, one must determine whether the examined area can be ascribed to a plane surface or not so that water enters the VFS in a more or less concentrated way. This should be accounted for in the second step (buffer zone efficiency modelling) by increasing the incoming hydrograph of corresponding proportions of the VFS non-efficient/total length.

Thus, for a given VFS position, modelling scenario definition involves selecting a season, rainfall length and intensity, soil occupation (and crop state of development) and antecedent humidity status; the latter two factors allow one to define the corresponding Curve Number based on the contributive area soil. This choice should be based on main periods of pesticide application to take into account main risk contamination periods.

\section{II.3 Buffer zone efficiency modelling approach}

A numerical overland flow and transport model is used to simulate the vegetative buffer zone efficiency of the defined scenario. The VFSMOD model (Munoz-Carpena et al., 2010) is a physically based model that calculates infiltration volume and sediment trapping levels in a buffer over a defined event (rainfall hyetograph, runoff hydrograph and sediment characteristics entering the filter). Using the optimization mode allows one to determine which width is optimal with respect to the required efficiency level. Concentrated flows in a filter can be taken into account by reducing the effective flow dimension of the strip perpendicular to the flow (called FWIDTH in VFSMOD) or by reducing dimensions of the field or source area edge (Muñoz-Carpena and Parsons, 2004, Fox et al., 2010, Dosskey et al. 2011). Water tables can drastically lower the buffer zone capacity to infiltrate water, and particularly for fine soils (Simpkins et al., 2002; Arora et al., 2010; Lacas et al., 2005, Lauvernet and Muñoz-Carpena, submitted). The vertical infiltration level is then determined using the SWINGO algorithm coupled to other processes, as it takes into account the effect of a shallow water table underlying a buffer zone (Muñoz-Carpena et al., submitted). Sediment trapping efficiency is based on sediment transport equations (Muñoz-Carpena et al., 1999) by simulating the filtration of suspended solids through artificial grass media. An extension that allows one to assess pesticide dissipation in the VFS was recently added to VFSMOD (Sabbagh et al., 2009). Yet, this extension is based on statistical regressions derived from observations on a range of efficient VFS values: it does not explicitly represent processes involved in pesticide behaviour.

Three classes of characteristics or parameters must be defined to use VFSMOD and to characterize the VFS infiltration capacity: (i) its topography and dimensions, (ii) soil hydrodynamic characteristics at the surface and in the soil, and (iii) initial humidity status and the presence or absence of a water table. The effective length (perpendicular to the flow) of the buffer zone must be determined to simulate its efficiency using VFSMOD. In the field, it is better to maximally prevent runoff concentration, preferably through the implantation of dispersive facilities. The length can be parameterized in several ways: field measurements or through the use 
Author-produced version of the article published in Science of The Total Environment, Volume 575, 1 January 2017, Pages 701-712 The original publication is available at http://www.sciencedirect.com/ http://dx.doi.org/10.1016/j.scitotenv.2016.09.105 This manuscript version is made available under the CC-BY-NC-ND 4.0 license

of a GIS tool that considers runoff concentrations. Similarly, slopes can be determined through field measurements or by using a GIS. Saturated hydraulic conductivity is a key parameter of the model and is often the most influential, together with water table depth depending on the hydraulic loading (Muñoz-Carpena et al., 2010; Lauvernet and Muñoz-Carpena, submitted). It is therefore important to assign a value as representative as possible of the real conductivity value. It is thus possible to consider two distinct horizons: the root mat and the rest of the vertical profile. These are then combined through a harmonic mean as recommended by Bouwer (1969). As is done for the contributory surface, the presence or absence of a shallow water table is determined through field observations or through the use of database (e.g., the DONESOL database for France and the USGS database for the US). Other parameters affect buffer efficiency less and can be set as default values (including sediment characteristics), as the main assumptions of this method consider runoff reduction only. However, for a user with access to the necessary data, VFSMOD allows one to study other processes such as the transport of sediment and pesticides.

The output of the model in optimization mode gives the outflow surface runoff percentage of the buffer area according to the width for each scenario, on a width range set by the user. The desired level of efficiency allows one to graphically visualize the necessary width for each typical rainfall event. Figure 4 presents $70 \%$ efficiency sizing results for a rainfall event set at $21 \mathrm{~mm}$ for 6 hours (“Summer, Moderate, $6 \mathrm{~h}$ ” of Figure 3).

Thus, this toolkit allows one to define scenarios that correspond closely to the considered buffer zone project in regards to rainfall events, contributive areas, and buffer zone areas, and to their characteristics evolution year round. This allows one to carefully optimize buffer zones and to achieve desired efficiency levels without consuming more agricultural surface area than is necessary.

\section{Application on a test catchment}

\section{III.1 Design method implementation}

The application site is the Fontaine du Theil catchment (128 ha) near Rennes in western France. The climate is temperate oceanic with a nearly $12^{\circ} \mathrm{C}$ mean annual air temperature, an approximately $800 \mathrm{~mm}$ mean annual precipitation level since the early 1990's and a $750 \mathrm{~mm}$ mean annual potential evapotranspiration level. Crop rotations involve maize, wheat and meadows in equal proportions of the total catchment area. Slopes are moderate with an average of $3.9 \%$ and a standard deviation of $2.7 \%$. Soils have developed on rather impermeable schist and can be classified into three main types: G1 for hill-slope brown soil, G2 for hill-slope leached brown soil and G3 for low-lying hydromorphic brown soil. Erreur! Source du renvoi introuvable. presents a soil map of the area. Soils here are quite shallow, and thus a water table usually lies on the schist layer. Its roof can be near the soil surface, in particular along the valley bottom in the winter. As a consequence, surface runoff occurs quite frequently, and especially in low-lying areas. In addition, depending on crop and tillage practices used, soils can be subject to slaking, leading to surface runoff. Shallow lateral flows on the hill-slopes supply river flows, which can stop during drier summers.

A field diagnosis of soil distributions, soil occupation patterns, potential buffer zones (vegetated buffer zones, hedges and embankments), water short circuits (ditches, tile drainage, and roads) and consequent water 
Author-produced version of the article published in Science of The Total Environment, Volume 575, 1 January 2017, Pages 701-712 The original publication is available at http://www.sciencedirect.com/ http://dx.doi.org/10.1016/j.scitotenv.2016.09.105 This manuscript version is made available under the CC-BY-NC-ND 4.0 license

pathways involving agronomists, hydrologists and farmers was performed for the watershed. We in turn identified zones where surface runoff is most likely to occur and pesticide fluxes to be generated. From this analysis, a range of vegetative buffer strip potential positions was identified as illustrated in Figure 5 . To design the resulting VFS, contributive areas characteristics were assessed and namely topographic characteristics and curve numbers. The former were calculated using a GIS and the corresponding results are presented in Erreur ! Source du renvoi introuvable. Scenarios must be chosen carefully, as they determine the resulting VFS size. Such scenarios must represent a variety of realistic situations for the considered catchment. Each scenario is defined by one rainfall event (duration and intensity), one crop and an initial humidity state for the contributive area. Based on expert knowledge, twelve different scenarios were considered for the Fontaine du Theil catchment: (i) For the winter period, two crops were taken into account: winter wheat and intermediate nitrate trapping crops (assimilated to meadows). Wheat was considered poorly developed (10\% of soil cover) whereas trapping crops were considered well developed. A 24-hour-long moderately intensive rainfall period was considered in addition to a 3-hour-long intensive one (Erreur ! Source du renvoi introuvable.). For the former, soils were considered to be moderately wet at the beginning of the event, when they were considered to be wet for the second case. According to piezometer data available on the catchment, the water table was supposed to be 5 meters deep for $\mathrm{G} 1$ and $\mathrm{G} 2$ soils and 1 meter deep for G3 soils. (ii) For the summer period, both winter wheat and corn crops were considered, and two rainfall events were taken into account: a 2-hourlong intensive event and a 6-hour-long moderately intensive event. For each crop and rainfall event, intermediate and initially high soil humidity conditions were modelled. Here, wheat was considered well developed (90\% soil covering) when maize was deemed recently seeded (25\%). The water table depth was set to $5 \mathrm{~m}$ for $\mathrm{G} 1$ and $\mathrm{G} 2$ soils and to $2.5 \mathrm{~m}$ for $\mathrm{G} 3$ soils.

The surface layer conductivity level estimated using SWC (Soil Water Characteristics software, Saxton and Rawls, 2006) was considered to assess the curve number value for each case. Original Curve Number tables were initially proposed for North American conditions based on data for a range of small American rural catchments. Yet, an analysis of three experimental sites in France (northern France with permeable and silty but highly capping soils, western France with less permeable and moderately loamy clay soils and southeastern France with very permeable clayed sand) for which data were available showed that CN values derived from USDA tables were systematically too low to make runoff predictions. Increasing these original CN values by 7-8 points made it possible to satisfactorily represent the observed runoff of the three sites. As a result, for this application, CN values derived from USDA tables were also increased by 8 points. Erreur! Source du renvoi introuvable. summarizes these values.

For vegetative filter strip soil Van Genuchten parameters, each second soil layer was taken into account because for this catchment on low permeable schists, this layer's infiltration effects heavily influence surface runoff generation. Yet, in regards to saturated hydraulic conductivity, a harmonic mean of $15 \mathrm{~cm}$ for the first layer and of $35 \mathrm{~cm}$ for the second layer was used. These parameters were also derived using SWC software and are summarized in Erreur ! Source du renvoi introuvable.. 
Author-produced version of the article published in Science of The Total Environment, Volume 575, 1 January 2017, Pages 701-712 The original publication is available at http://www.sciencedirect.com/ http://dx.doi.org/10.1016/j.scitotenv.2016.09.105 This manuscript version is made available under the CC-BY-NC-ND 4.0 license

\section{III.2 Results and discussion}

Taking into account the hydrodynamics of flows in this catchment, a typical catchment of western France (Gascuel Odoux et al., 2010; Rouxel et al., 2011),, our risk contamination diagnosis led us to set vegetated buffer zones at the hill-slope base in addition to pre-existing buffer zones (banks, hedges and vegetated buffer zones) as is illustrated in Figure 5. The figure shows optimal VFS sizes determined via this method. In addition to intercepting all surface runoff generated on hill-slopes, such a position is consistent with optimal agrienvironmental conditions prescribed in France. Moreover, it minimizes drawbacks of VFS implantation for farmers. Yet, as the experts who performed the diagnosis were aware of hydromorphic characteristics of lowaltitude areas and as surface runoff fluxes are maximal at the hill-slope bases of such catchments, they proposed an alternative or supplementary implantation of some buffer zones that are situated on G3 soil and/or are bound to experience large surface runoff fluxes. When a grass strip is located on low-lying land on hydromorphic soil with an underlying shallow water table (e.g., n56, n62, or n26), its effectiveness is limited, resulting in widths exceeding 25 meters. Conversely, n25 located just above n26 intercepts an area similar to that collected by $n 26$, although it is slightly lower $\left(146 \mathrm{~m}^{2}\right.$ of the contributive area per meter of VFS for $n 25$ versus $156 \mathrm{~m}^{2}$ of the contributive area per meter of VFS for n26). However, as it is located on healthy soil with a deep water table that does not interfere with its infiltration, its width may be more moderate. Findings are similar for n17, which is situated on permeable soil (G1) but which accumulates a large area (204 $\mathrm{m}^{2}$ per meter of VFS). If this buffer zone is supposed to exist alone on the hill-slope, the most demanding scenario involves a 14.25 m width VFS when 9.25 is sufficient when a VFS (n28) is implanted higher on the hill-slope. The total area (right-of-way) generated from two VFSs is similar to that based on one, but the first solution eliminates more sediment and is thus preferred.

Effects of the different scenarios show that winter scenarios lead to narrow VFSs provided that infiltration is possible (i.e., when the water table is not too shallow). This is related to the pluviometric context of this area, where winter rainfall events are frequent and long but moderate in intensity, causing soil hydraulic conductivity to almost never be exceeded (see Figure 3). By contrast, summer scenarios with high initial moisture conditions (III) lead to high widths and especially when contributive areas are supposed to be seeded with corn, corresponding to low soil cover at the beginning of the summer and thus a high curve number. This shows that results are shaped heavily by chosen scenarios, which should emanate from discussions with stakeholders. In the same way, design selection should involve a compromise between the targeted efficiency and acceptable dimensions, and possibly by relativizing the significance of some very adverse scenarios.

When applied to the Fontaine du Theil Catchment, the proposed design method allows one to design each buffer zone individually. Yet, processing the entire method for each buffer zone proved quite tedious. As a result, we decided to develop an alternative approach based on a broad range of pre-calculated scenarios and resulting in ready-to-use nomograms. This approach is briefly presented in the following section. 
Author-produced version of the article published in Science of The Total Environment, Volume 575, 1 January 2017, Pages 701-712 The original publication is available at http://www.sciencedirect.com/ http://dx.doi.org/10.1016/j.scitotenv.2016.09.105 This manuscript version is made available under the CC-BY-NC-ND 4.0 license

\section{Towards a more user-friendly approach}

The proposed approach is based on the definition and pre-calculation of a large number of scenarios covering a wide range of conditions and making it possible to build nomograms where the user can select the result that best reflects his own situation. Two climates were considered. The first, a northern oceanic temperate climate ( $\mathrm{N}$ in the nomograms), is based on Amiens data (Northern France: $\mathrm{X}=597212 \mathrm{~m}$; Y = $2543947 \mathrm{~m}$ in Lambert II). The mean annual precipitation level here is $771 \mathrm{~mm}$. The second is a southern Mediterranean climate (S in the nomograms) based on Roujan data (Southern France: $X=678888 \mathrm{~m} ; \mathrm{Y}=1834131 \mathrm{~m}$ ). The mean annual rainfall level here is $654 \mathrm{~mm}$. Monthly rainfall levels are presented in Figure 6.

For each representative climatic region, three realistic worst-case rainfall events were considered: one 12hour-long winter rainfall event and two summer events (one 2 hours long and one 6 hours long) (Table 3).

Contributive areas were considered to be rectangular and planar, feeding a buffer zone of the same dimension. When this was not the case (trapezoidal forms in the contributive area or flows converging into a talweg), we took this into account by considering an equivalent contributive area length. Simulations considered slope lengths (assuming a rectangular field) of $50 \mathrm{~m}$ to $300 \mathrm{~m}$ at $50 \mathrm{~m}$ increments and contributive area slopes of 2, 5 and $10 \%$.

Simulations were performed for the four classes of soils ( $A$ to $D$ ) distinguished by the USDA and assuming that: (i) winter crop is wheat and summer crop is corn ; (ii) initial humidity level is high in the winter (III) and either at field capacity (II) or high (III) in the summer. Curve values used for the simulations are summarized in Erreur ! Source du renvoi introuvable.. Equation 1 was used to assess curve numbers for humidity conditions III). Following Brown et al. (2012), four classes of soils were considered as vegetative buffer zones in the VFS scenario project: silt loam, sandy loam, clay loam and sandy clay loam. Soil parameters were assessed via the Rosetta pedotransfer function (Schaap et al, 2001) for $n$, alpha and Theta_r. Ksat and Theta_s values were drawn from Brown et al. (2012), as they take into account soil structure modifications induced by perennial vegetation. Two initial water table depths were simulated: $2.5 \mathrm{~m}$ and $1 \mathrm{~m}$. To make realistic calculations, for a given VFS, simulated water table depths were combined for the summer and winter as follows: $2.5 \mathrm{~m}$ in the winter and $2.5 \mathrm{~m}$ in the summer, $1 \mathrm{~m}$ in the winter and $2.5 \mathrm{~m}$ in the summer, and $1 \mathrm{~m}$ in the winter and $1 \mathrm{~m}$ in the summer. Initial humidity conditions are set at hydrostatic equilibrium above the water table. The VFS slope must be the same as the contributive area's slope: 2,5 and 10\%. These combinations led to 4,284 scenarios. 11 VFS widths were simulated for each scenario (from 5 to $25 \mathrm{~m}$ ) generating nearly 50,000 simulations. This allowed us to assess an optimal VFS width for each set of scenarios with $\mathbf{7 0 \%}$ efficiency. This means at least 70 $\%$ of the incoming water (runoff + rain) was infiltrated within the vegetative buffer zone soil (or $30 \%$ may reach downslope areas) for the four rainfall and humidity status scenarios defined for a given VFS situation. As suspended matter can deposit upslope of a VFS and adsorption can occur on VFS soil, a VFS can be oversized for $70 \%$ efficiency. In any case, a VFS must also prove efficient for low sorbing pesticides, and $30 \%$ of incoming water may still exit a strip during a yearly maximum runoff event. The $70 \%$ efficiency level selected for this application may seem arbitrary. It is designed to be pragmatic in consideration of constraints on farmers. We made a compromise, as reducing risks of transfers to zero does not seem reasonable: such a choice would also require one to consider less frequent and more intense rainfall events with the corresponding return period 
Author-produced version of the article published in Science of The Total Environment, Volume 575, 1 January 2017, Pages 701-712 The original publication is available at http://www.sciencedirect.com/ http://dx.doi.org/10.1016/j.scitotenv.2016.09.105 This manuscript version is made available under the CC-BY-NC-ND 4.0 license

also being arbitrary. In addition, the most intensive runoff events do not necessarily coincide with the highest pesticide concentrations and fluxes. Pesticide concentrations and fluxes in surface runoff are mainly dependent on time between application and rainfall, which determines available pesticide storage levels. Pesticide concentrations in surface runoff are higher when surface water flows are low (models usually consider perfect mixing between surface water and a given depth of soil), but exported amounts are higher when water cumulated discharge is higher.

Figure 7 presents a nomogram including several informations. The blue curve represents the size of the optimal buffer zone for a given contributive area length for the winter rainfall event (15 mm falling over 12 hours with moderate maximal intensity) and an intermediate slope of $5 \%$. The blue shadow area shows how the buffer size varies with different slopes (the higher the slope, the wider the buffer, with slopes varying from 2 to $10 \%$ in the performed simulations). For example, when the contributive area length is $125 \mathrm{~m}$, the optimal buffer width is roughly $7.5 \mathrm{~m}$. When the optimal size is greater than $25 \mathrm{~m}$, the exact value is not calculated (denoted by a value of $25+$ ), as this may mean that a vegetated filter strip may not be the best or only necessary mitigation solution. Typically, an artificial wetland area can be more efficient in such cases or may need to be used in addition to a reduced buffer width of less than $20 \mathrm{~m}$. The yellow curve corresponds to the worst scenario with summer rainfall falling on soil at field capacity. Depending on the situation, this can involve $17 \mathrm{~mm}$ of rainfall falling for 6 hours with moderate maximal intensity or $12 \mathrm{~mm}$ of rainfall falling for 2 hours with high maximal intensity. For this example, the second case is the worst scenario. Looking at Figure 7hillslope, when the contributive area length reaches $125 \mathrm{~m}$, a 5-meter-wide buffer is sufficient. The grey curve illustrates a case whereby a rainfall event occurs on wet soil in the summer with moderate rain of $17 \mathrm{~mm}$ falling over 6 hours. Successive rainfall events occurring in the summer can create wet soil. This simulation illustrates that buffers work in certain situations but do not guarantee zero risk when several adverse conditions are involved. The explored scenarios and generated abacus are still prospective and are designed to assess the feasibility of the proposed approach.

\section{Conclusions and perspectives}

The design methodology presented here allows one to consider a broad range of local characteristics (hydrodynamic characteristics of a contributive area and VFS soils, crops, rainfall events, and seasons) in optimally designing vegetated buffer strips based on local conditions. For a given buffer zone, different widths are obtained for individual agronomic and climatic scenarios. As a consequence, final selection will depend on the size of action plan objectives and ambitions: a width is selected to cover the whole set of scenarios provided that establishing such a buffer zone is reasonable from an operational point of view. Such an approach allows one to generate a VFS large enough to be efficient without consuming unnecessarily large agricultural surfaces. However, one must be aware that VFSs must be used along with sound agricultural practices and that regardless of their size, they cannot fully prevent pesticide entry into surface water, where even low quantities of pesticides may have significant ecotoxicological effects depending on their ecotoxicological properties. In some unfavourable cases (flow concentrations or waterlogged soils), the method will generate VFS widths that are too large from a farmer's perspective. These results will then serve as an 
Author-produced version of the article published in Science of The Total Environment, Volume 575, 1 January 2017, Pages 701-712 The original publication is available at http://www.sciencedirect.com/ http://dx.doi.org/10.1016/j.scitotenv.2016.09.105 This manuscript version is made available under the CC-BY-NC-ND 4.0 license

impartial basis to initiate dialog between different stakeholders on possible solutions. These can involve various outcomes, e.g., better runoff dissemination, buffer zone completion using other devices or buffer zones higher up on hill-slopes (reducing the contributive area of the studied buffer zone), or moving a buffer zone to a more favourable area (e.g., an area without waterlogging). Thus, the location and sizing of buffer zones on a watershed can be a recursive task. To guarantee the acceptability of results, it seems necessary that definitions of "typical" scenarios and of desired levels of efficiency are discussed with stakeholders. Given processes considered through the proposed method (namely surface runoff attenuation), the design method may apply to contaminants other than pesticides submitted through similar processes (e.g., veterinary medicines, pathogens, phosphorus or heavy metals). However, as nitrogen exportation occurs mainly through subsurface flows, the proposed method does not seem applicable to cases of nitrogen contamination.

To our knowledge, the proposed methodology is the first to explicitly consider shallow water tables, which are commonly found in VFS locations, and especially those along waterways. Yet, the method is still limited, at least in the form presented here, as it does not consider suspended matters or pesticide transfer and dissipation within a VFS. In fact, this should be partly possible, as VFSMOD can manage suspended matter deposition and pesticide transfer attenuation (using a statistic relation) as stated above. Yet, it must be stressed that data on hill-slope erosion or pesticide application are rare and that one must ensure data quality before addressing such questions. In addition, the main process involved in VFS efficiency is water infiltration within buffer soils. As a consequence, except when only strongly sorbed pesticides are used in a very erosive context, it seems more relevant to focus data acquisition efforts on soil data. Rather, results are heavily dependent on the contributive curve number, on the hydraulic conductivity of the buffer zone soil, and of course on the presence or absence of a shallow water table (Lauvernet and Muñoz-Carpena, submitted). Another limitation pertains to the fact that infiltrated water and pesticide fates are not considered: in certain contexts, it may be necessary to consider possible subsurface lateral flows towards a stream or percolation into a vulnerable aquifer.

Our application of the method to the La Fontaine du Theil catchment led to relevant results, but applying the sizing method to each buffer zone individually proved quite tedious. This recognition led to the development of nomograms based on numerous simulations covering a wide range of scenarios in consideration of climatic, soil, topographical and crop features. These nomograms are easier to use, and yet their sound application requires providing data and adhering to the hypothesis of the present method. The complete method, nevertheless, will still prove useful in specific situations not covered by the pre-simulated scenarios. These nomograms must be enriched with more scenarios. Such work is currently on-going for a wider range of curve numbers and rainfall scenarios that cover the entire French territory and a user-chosen level of efficiency. The resulting tool will be freely accessible online. It could be extended to other countries provided rainfall data are available. Such nomograms could be applied to refine the homologation process employed in step 4 . They could also be used for purposes of contamination risk management (e.g., in the case of permanent vegetated devices which are now compulsory in France to commercialize certain phytosanitary products (MAAP, 2006), whereby they could allow for the protection surface water without becoming oversized. 
Author-produced version of the article published in Science of The Total Environment, Volume 575, 1 January 2017, Pages 701-712 http://dx.doi.org/10.1016/j.scitotenv.2016.09.105 This manuscript version is made available under the CC-BY-NC-ND 4.0 license

\section{Acknowledgements}

This work was achieved within the framework of a research and development project funded by the French Agriculture Ministry, which determines agricultural policies (DGPAAT. Convention MAAF(DGPAAT / S Dir B\&E / BSE) - Irstea. Agriculture et gestion durable de l'eau- 2012-2014) focused on developing an operational VFS sizing method. The abacus study was funded by the ECPA through the TOPPS-Prowadis project (http://www.topps-life.org) aimed at developing methods and tools for protecting water from non-point pesticide pollution. Irstea directed the VFS diagnosis and sizing work. The authors wish to thank Clotaire Catalogne, Guy Le Hénaff and Jean-Joel Gril fortheir contributions and Alexandra Fontaine for providing an early version of the contributive area hydrograph assessment tool using a spreadsheet..

\section{References}

Arora, K., Mickelson, S.K., Baker, J.L., Tierney, D.P., Peters, C.J., 1996. Herbicide retention by vegetative buffer strips from runoff under natural rainfall. Trans. ASAE 39, 2155-2162.

Arora, K., Mickelson, S.K., Helmers, M.J., Baker, J.L., 2010. Review of Pesticide Retention Processes Occurring in Buffer Strips Receiving Agricultural Runoff1. JAWRA Journal of the American Water Resources Association 46, 618-647. doi:10.1111/j.1752-1688.2010.00438.x

Aubert, Y., Arnaud, P., Ribstein, P., Fine, J.-A., 2014. The SHYREG flow method-application to 1605 basins in metropolitan France Hydrological Sciences Journal. 59, 993-1005.

Bernard, K., Carluer, N., Le Henaff, G., 2014. Limitation du transfert hydrique des produits phytosanitaires par les zones tampons: caractérisation de l'existant et propositions de dispositifs correctifs et complémentaires. Techniques Sciences Méthodes 83-99. doi:10.1051/tsm/201412083 (in French).

Beven, K.J., Wood, E.F., Sivapalan, M., 1988. On hydrological heterogeneity - Catchment morphology and catchment response. Journal of Hydrology 100, 353-375. doi:10.1016/0022-1694(88)90192-8

Brown, C., Balderacchi, M., van Beinum, w., Capri, E., Trevisan, M., 2012. Definition of vegetative filter strip scenarios for Europe. Environment Department, University of York, Heslington, York, YO10 5DD, UK, p. pp. 71.

Bouwer, H., 1969. Infiltration of water into nonuniform soil. Journal of Irrigation and Drainage Division 95, 451462.

Carluer, N., Noll, D., Bernard, K., Fontaine, A., Lauvernet, C., 2014. Dimensionner les zones tampons enherbées et boisées pour réduire le transfert hydrique des produits phytosanitaires. Techniques, Sciences et Méthodes 12, 101-120 (in French).

Chow, V.T., Maidment, D.R., Mays, L.W., 1988. Applied Hydrology. New York.

CORPEN, 2007. Les fonctions environnementales des zones tampons - Les bases scientifiques et techniques des fonctions de protection des eaux, première édition, Comité d'orientation p our des pratiques agricoles respectueuses de l'environnement.

CORPEN, 1997. Produits phytosanitaires et dispositifs enherbés - État des connaissances et propositions de mise en œuvre. Comité d'orientation pour la réduction de la pollution des eaux par les nitrates, les 
Author-produced version of the article published in Science of The Total Environment, Volume 575, 1 January 2017, Pages 701-712 The original publication is available at http://www.sciencedirect.com/ http://dx.doi.org/10.1016/j.scitotenv.2016.09.105 This manuscript version is made available under the CC-BY-NC-ND 4.0 license

phosphates et les $\mathrm{p}$ roduits phytosanitaires provenant des activités agricoles.

Daniels, R.B., Gilliam, J.W., 1996. Sediment and Chemical Load Reduction by Grass and Riparian Filters. Soil Science Society of America Journal 60, 246. doi:10.2136/sssaj1996.03615995006000010037x

Devers-Lamrani, M., Pesce, S., Rouard, N., Martin-Laurent, F., 2014. Evidence for cooperative mineralization of diuron by Arthrobacter sp. BS2 and Achromobacter sp. SP1 isolated from a mixed culture enriched from diuron exposed environments. Chemosphere 117, 208-215. doi:10.1016/j.chemosphere.2014.06.080

Dosskey, M.G., Helmers, M.J., Eisenhauer, D.E., 2006. An Approach for Using Soil Surveys to Guide the Placement of Water Quality Buffers. Journal of Soil and Water Conservation 61, 344-354.

Dosskey, M.G., M.J. Helmers, D.E. Eisenhauer. 2008. A design aid for determining width of filter strips. Journal of Soil and Water Conservation 63(4):232-241, doi:10.2489/jswc.63.4.232.

Dosskey, M.G., Helmers, M.J., Eisenhauer, D.E., 2011. A design aid for sizing filter strips using buffer area ratio. Journal of Soil and Water Conservation 66, 29-39. doi:10.2489/jswc.66.1.29

Fox, G., Munoz-Carpena, R., Sabbagh, G., 2010. Influence of flow concentration on parameter importance and prediction uncertainty of pesticide trapping by vegetative filter strips. Journal of Hydrology 384, 164173. doi:10.1016/j.jhydrol.2010.01.020

Gascuel Odoux, C., Weiler, M., Molenat, J., 2010. Effect of the spatial distribution of physical aquifer properties on modelled water table depth and stream discharge in a headwater catchment. Hydrol. Earth Syst. Sci 14, 1179-1194.

Helmers, M.J., Isenhart, T.M., Dosskey, M., Dabney, S.M., Strock, J.S., 2008. Buffers and Vegetative Filter Strips. USDA Forest Service / UNL Faculty Publications.

Lacas, J.-G., Voltz, M., Gouy, V., Carluer, N., Gril, J.-J., 2005. Using grassed strips to limit pesticide transfer to surface water: a review. Agron. Sustain. Dev. 25, 253-266. doi:10.1051/agro:2005001

Lacas, J.-G., Carluer, N., Voltz, M., 2012. Efficiency of a Grass Buffer Strip for Limiting Diuron Losses from an Uphill Vineyard Towards Surface and Subsurface Waters. Pedosphere 22, 580-592. doi:10.1016/S1002-0160(12)60043-5

Lauvernet, C. and Muñoz-Carpena, R., submitted. Shallow water table effects on water, sediment and pesticide transport in vegetative filter strips, II. Overland flow and transport coupling, factor importance and uncertainty.

Lowrance, R., Hubbard, R.K., Williams, R.G., 2000. Effects of a managed three zone riparian buffer system on shallow groundwater quality in the southeastern Coastal Plain. Journal of Soil and Water Conservation $55,212-220$.

MAAP (2006). Arrêté du 12 septembre 2006 relatif à la mise sur le marché et à l'utilisation des produits visés à l'article L. 253-1 du code rural et de la pêche maritime

Madrigal-Monarrez, I., 2004. Rétention de pesticides dans les sols des dispositifs tampon, enherbés et boisés. Rôle des matières organiques. Institut Agronomique Paris-Grignon, p. 212

Muñoz-Carpena, R., Parsons, J.E., Gilliam, J.W., 1999. Modeling hydrology and sediment transport in vegetative filter strips. Journal of Hydrology 214, 111-129. doi:10.1016/S0022-1694(98)00272-8 
Author-produced version of the article published in Science of The Total Environment, Volume 575, 1 January 2017, Pages 701-712 The original publication is available at http://www.sciencedirect.com/ http://dx.doi.org/10.1016/j.scitotenv.2016.09.105 This manuscript version is made available under the CC-BY-NC-ND 4.0 license

Muñoz-Carpena, R., Parsons, J.E., 2004. A design procedure for vegetative filter strips using VFSMOD-W. Transactions of the ASAE 47, 1933-1941. doi:10.13031/2013.17806

Muñoz-Carpena, R., Fox, G., Sabbagh, G., 2010. Parameter Importance and Uncertainty in Predicting Runoff Pesticide Reduction with Filter Strips. Journal of Environmental Quality 39, 630-641. doi:10.2134/jeq2009.0300

Muñoz-Carpena, R., Lauvernet, C, Carluer, N., submitted. Shallow water table effects on water, sediment and pesticide transport in vegetative filter strips, I. Unsteady rainfall infiltration and soil water redistribution.

Park, Y.S., Engel, B.A., Shin, Y., Choi, J., Kim, N.-W., Kim, S.-J., Kong, D.S., Lim, K.J., 2013. Development of Web GIS-Based VFSMOD System with Three Modules for Effective Vegetative Filter Strip Design. Water 5, 1194-1210. doi:10.3390/w5031194

Poletika, N.N., Coody, P.N., Fox, G.A., Sabbagh, G.J., Dolder, S.C., White, J., 2009. Chlorpyrifos and Atrazine Removal from Runoff by Vegetated Filter Strips: Experiments and Predictive Modeling. Journal of Environmental Quality 38, 1042-1052. doi:10.2134/jeq2008.0404

Reichenberger, S., Bach, M., Skitschak, A., Frede, H.-G., 2007. Mitigation strategies to reduce pesticide inputs into ground- and surface water and their effectiveness; A review. Science of The Total Environment 384, 1-35. doi:10.1016/j.scitotenv.2007.04.046

Rouxel, M., Molénat, J., Ruiz, L., Legout, C., Faucheux, M., Gascuel-Odoux, C., 2011. Seasonal and spatial variation in groundwater quality along the hillslope of an agricultural research catchment (Western France). Hydrol. Process. 25, 831-841. doi:10.1002/hyp.7862

Sabbagh, G.J., Fox, G.A., Kamanzi, A., Roepke, B., Tang, J.-Z., 2009. Effectiveness of Vegetative Filter Strips in Reducing Pesticide Loading: Quantifying Pesticide Trapping Efficiency. J. Environ. Qual. 38, 762. doi:10.2134/jeq2008.0266

Saxton, K.E., Rawls, W.J., 2006. Soil Water Characteristic Estimates by Texture and Organic Matter for Hydrologic Solutions. Soil Science Society of America Journal 70, 1569-1578. doi:10.2136/sssaj2005.0117

Schaap, M.G., Leij, F.J., van Genuchten, M.T., 2001. rosetta: a computer program for estimating soil hydraulic parameters with hierarchical pedotransfer functions. Journal of Hydrology 251, 163-176. doi:10.1016/S0022-1694(01)00466-8

Simpkins W, Wineland T, Andress R, Johnston D, Caron G, Isenhart T, Schultz R, 2002. Hydrogeological constraints on riparian buffers for reduction of diffuse pollution: examples from the Bear Creek watershed in lowa, USA. Water Science and Tech. 45, 61-68.

Tomer, M., Dosskey, M., Burkart, M., James, D., Helmers, M., Eisenhauer, D., 2008. Methods to prioritize placement of riparian buffers for improved water quality. Agroforestry Systems 17-25. doi:10.1007/s10457-008-9134-5

USDA-SCS, 1972. National Engineering Handbook, Part 630 Hydrology., Washington, D.C.

White, M.J., Arnold, J.G., 2009. Development of a simplistic vegetative filter strip model for sediment and nutrient retention at the field scale. Hydrol. Process. 23, 1602-1616. doi:10.1002/hyp.7291 
Table 7: Characterization of hydrologic soil groups for contributive areas (USDA, 1972).

\begin{tabular}{|c|c|c|c|c|}
\hline $\begin{array}{c}\text { SOIL - hydrology } \\
\text { groups }\end{array}$ & A & B & C & D \\
\hline Water transmission & Free & Still free & Somewhat restricted & Restricted \\
\hline Clay amount & $<10 \%$ & 10 to $20 \%$ & 20 to $40 \%$ & $>40 \%$ \\
\hline Sand / Gravel & $>90 \%$ & 50 to $90 \%$ & $<50 \%$ & $<50 \%$ \\
\hline Texture & Sand /Gravel & $\begin{array}{l}\text { Loamy sand, sandy } \\
\text { loam }\end{array}$ & $\begin{array}{l}\text { Silt loam, sandy clay } \\
\text { loam, silty clay loam }\end{array}$ & $\begin{array}{l}\text { Clay } \\
\text { (high shrinking and } \\
\text { swelling potential) }\end{array}$ \\
\hline Soil types & $\begin{array}{c}\text { Loamy sand, sandy } \\
\text { loam, silt loam }\end{array}$ & $\begin{array}{l}\text { Loam, silt loam, } \\
\text { sandy clay loam }\end{array}$ & $\begin{array}{c}\text { Clay, silty clay, sandy } \\
\text { clay }\end{array}$ & $\begin{array}{c}\text { Clay (impermeable } \\
\text { layer }<50 \mathrm{~cm} \text { high } \\
\text { water table) }\end{array}$ \\
\hline
\end{tabular}

\section{Additional materials}

-The VFSMOD model with a shallow water table is opensource and can be downloaded from http://abe.ufl.edu/carpena/vfsmod/.

-Nomograms resulting from simulations of the French scenarios shown in Tables 4 and 5 are in the file complete_nomograms_results.pdf

- Hyetohydro tool that generates hyetographs and hydrograms for France is available at ZT eq PollDiff@irstea.fr, as spreadsheets.

- The tool BUVARD online, which allows exploring nomograms and running the models within an interface will be available on Dec. 2016 on http://www.irstea.fr/la-recherche/unites-derecherche/maly/pollutions-agricoles-diffuses- 


\section{Table caption}

\section{9}

570
Table 1: Curve number values for the different scenarios. Curve numbers II and III respectively denote average and wet antecedent conditions. Unf and fav respectively denote unfavourable and favourable hydrological conditions.

Table 2: VFS soil parameters by soil type.

Table 3: Sizing (dimensions in meters) for each VFS and for each scenario studied for the Fontaine du Theil catchment. Dimensions are obtained for winter scenarios (in blue), summer conditions with 2 hours of rainfall (in orange), and summer conditions with 6 hours of rainfall (in green). VFS values denote to plots from which runoff is collected. The n17a addresses cases where the VFS $n 28$ is implemented, limiting the area intercepted by $n 17$. A width of $>25$ denotes any value obtained by the model that exceeds $25 \mathrm{~m}$. Int.crop denotes "Intermediate crop to trap nitrates". Ratio surface/length denotes: [contributive area surface/VFS length]. Slope designates the contributive area slope. For purposes of clarity, and because these VFSs run along several plots, $n 17$ concerns plots $17,18,27$ and 31 ; n60 concerns

Table 4: Representative rainfall event characteristics.

Table 5: Contributive area curve number values.

Table 6: Vegetative Filter Strip soil parameters. 
Author-produced version of the article published in Science of The Total Environment, Volume 575, 1 January 2017, Pages 701-712

The original publication is available at http://www.sciencedirect.com/ http://dx.doi.org/10.1016/j.scitotenv.2016.09.105 This manuscript version is made available under the CC-BY-NC-ND 4.0 license

Figure 1: Processes occurring in a grassed filter strip. From (Lacas et al., 2012)

Figure 2: Sizing method flowchart

Figure 3: Rainfall hyetographs on the Fontaine du Theil by season, duration, and type (left: moderate, right: intensive).

Figure 4: VFSMOD optimising example for the Fontaine du Theil catchment. The desired efficiency is a reduction of $70 \%$ of incoming runoff (green dotted line). Scenarios T1 to T4 correspond with upstream wheat crops (initial moisture conditions are average for T1 and wet for T2) and maize (initial moisture conditions are average for T3 and wet for T4). For the T1 scenario, a $5 \mathrm{~m}$ width is sufficient. The T2 scenario requires a width of $15 \mathrm{~m}$ to achieve the $70 \%$ efficiency level.

Figure 5: Fontaine du Theil Catchment soil map. Description of the plot and of soils in the river network and widths obtained for VFS. Dimensions in meters are obtained for winter scenarios (in blue), summer conditions with 2 hours of rainfall (in orange), and summer conditions with 6 hours of rainfall (in green). As it is not realistic to apply a VFS that exceeds $\mathbf{2 5} \mathrm{m}$ in width in France or in Europe more generally, any value above is written as '>25'.

Figure 6: Monthly rainfall (Average, 20th and 80th centiles). Left: northern scenario. Right: southern Mediterranean scenario.

Figure 7: Example of a buffer sizing nomogram for a northern France climate scenario. Region $\mathbf{N}$ denotes northern France climatic conditions; Soil A denotes the contributive area soil hydrological class; VFS Soil sL denotes that the buffer zone soil has a sandy loam texture; and W1m \& S2.5 m denotes the buffer zone location. The water table is very shallow in the winter $(1 \mathrm{~m})$ and deeper in the summer $(2.5 \mathrm{~m})$.

\section{Table 7:}

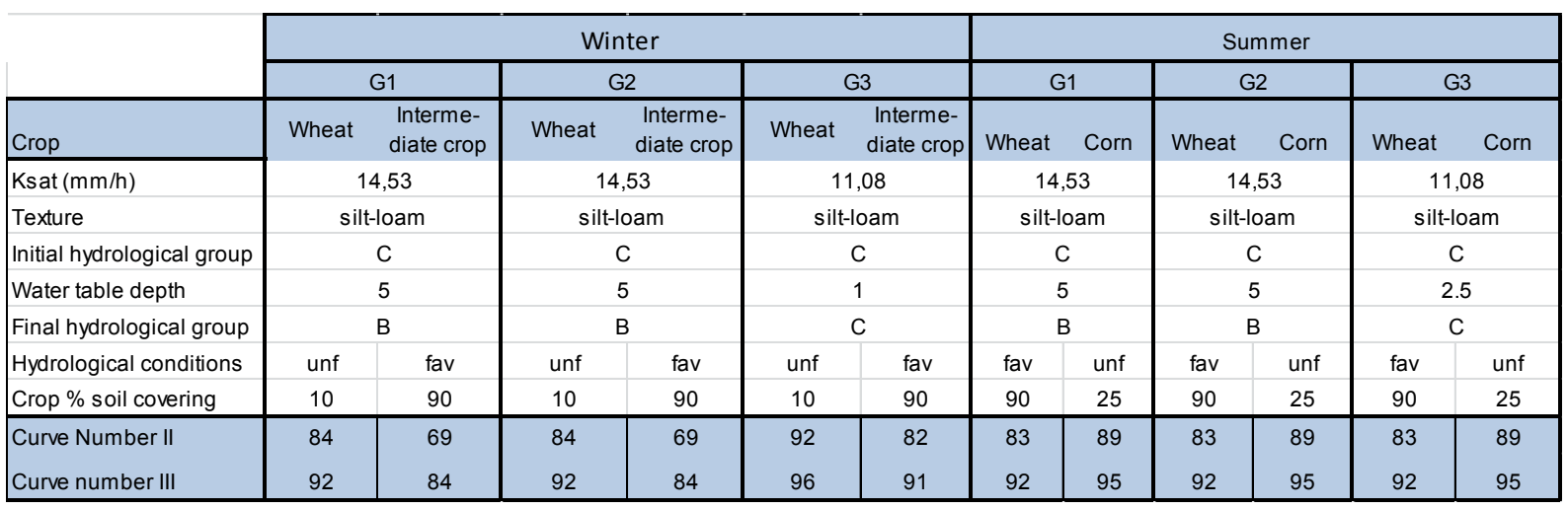

Table 8:

\begin{tabular}{l|c|c|c|} 
& $\mathrm{G} 1$ & $\mathrm{G} 2$ & $\mathrm{G} 3$ \\
\hline Reference layer & $\mathrm{B}$ & $\mathrm{E}$ & $\mathrm{S}$ \\
Ksat $(\mathrm{mm} / \mathrm{h})$ & 13.17 & 6.97 & 10.59 \\
$\mathrm{n}$ & 1.95 & 1.92 & 1.98 \\
alpha $\left(\mathrm{m}^{-1}\right)$ & 0.44 & 0.33 & 0.38 \\
$\mathrm{~m}$ & 0.49 & 0.48 & 0.49 \\
Saturated water content & 43.5 & 39.9 & 42.7 \\
Residual water content & 11.700 & 10.400 & 10.900 \\
\hline
\end{tabular}


Author-produced version of the article published in Science of The Total Environment, Volume 575, 1 January 2017, Pages 701-712

The original publication is available at http://www.sciencedirect.com/ http://dx.doi.org/10.1016/j.scitotenv.2016.09.105 This manuscript version is made available under the CC-BY-NC-ND 4.0 license

Table 9:

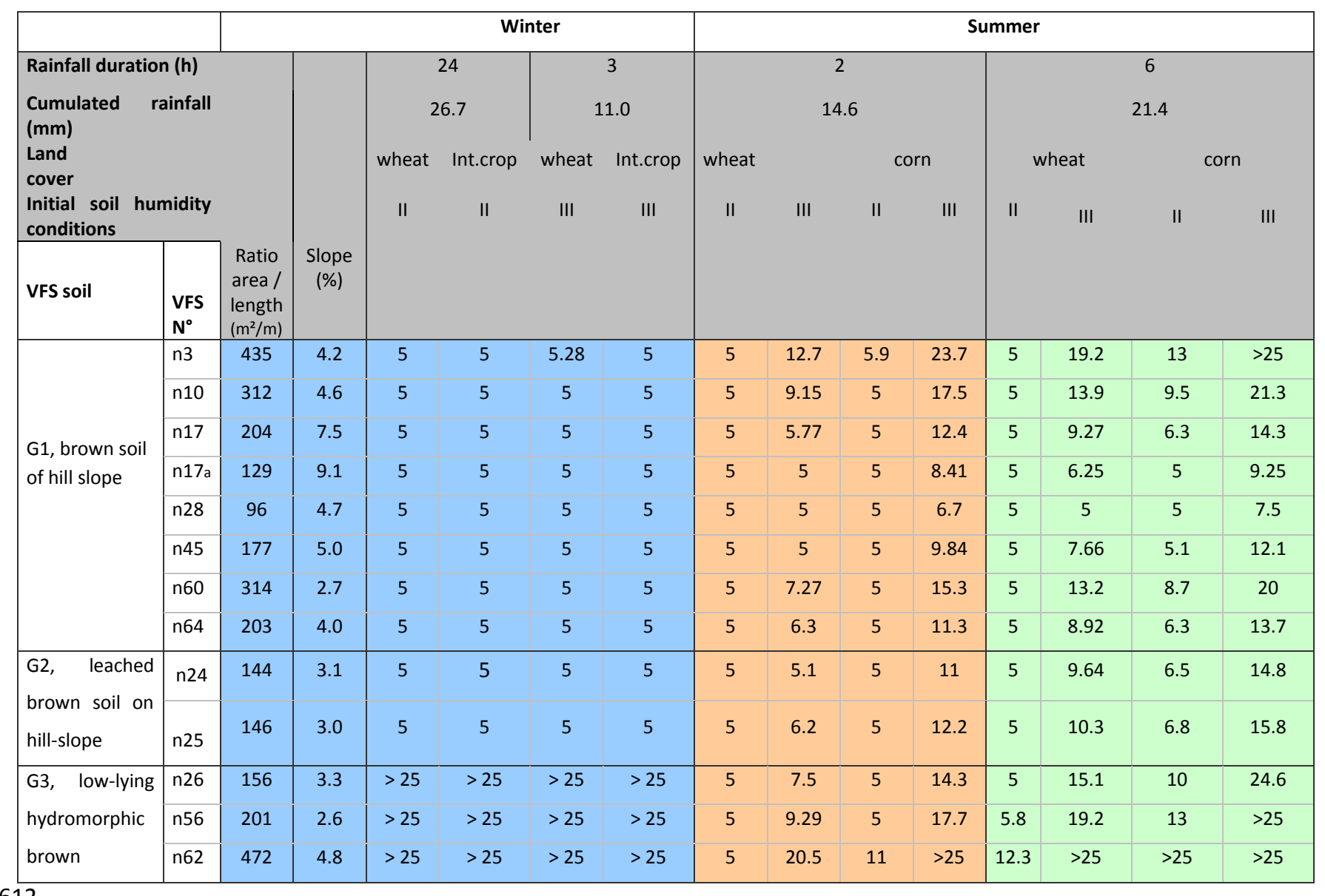

612

614 Table 10: Representative rainfall event characteristics.

\begin{tabular}{|l|c|c|c|c|c|c|}
\cline { 2 - 7 } \multicolumn{1}{c|}{} & \multicolumn{3}{c|}{ Northern France (Amiens) } & \multicolumn{3}{c|}{ Southern France (Roujan) } \\
\cline { 2 - 7 } & Winter (12 & Summer & Summer & Winter & Summer & Summer \\
$(2)$ & $h)$ & $(6 \mathrm{~h})$ & $(12 \mathrm{~h})$ & $(2 \mathrm{~h})$ & $(6 \mathrm{~h})$ \\
\hline Rainfall event volume $(\mathrm{mm})$ & 14.7 & 12.3 & 17.4 & 48.4 & 31.2 & 46.7 \\
\hline Type of rainfall event & Moderate & High & Moderate & Moderate & High & Moderate \\
\hline
\end{tabular}

615

Table 11: Contributive area curve number values.

\begin{tabular}{|l|c|c|c|c|}
\hline Winter: Wheat. & A & B & C & D \\
\hline Type of soil* & 70 & 81 & 89 & 93 \\
\hline Curve number value (Humidity condition: II) & 84 & 91 & 95 & 97 \\
\hline Curve number value (Humidity condition: III) & \multicolumn{5}{|l|}{} \\
\hline Summer: Corn. & A & B & C & D \\
\hline Type of soil* & 72 & 83 & 90 & 94 \\
\hline Curve number value (Humidity condition: II) & 86 & 92 & 95 & 97 \\
\hline Curve number value (Humidity condition: III) &
\end{tabular}


Author-produced version of the article published in Science of The Total Environment, Volume 575, 1 January 2017, Pages 701-712

The original publication is available at http://www.sciencedirect.com/ http://dx.doi.org/10.1016/j.scitotenv.2016.09.105 This manuscript version is made available under the CC-BY-NC-ND 4.0 license

Table 12: Vegetative Filter Strip soil parameters.

618

\begin{tabular}{|l|c|c|c|c|}
\hline VFS Soil & Silt loam & Sandy loam & Clay loam & $\begin{array}{c}\text { Sandy clay } \\
\text { loam }\end{array}$ \\
\hline Nomenclature & SIL & SAL & CLO & SCL \\
\hline $\mathbf{n}$ (Van Genuchten) & 1.6647 & 1.44 & 1.45 & 1.3636 \\
\hline Alpha (1/m) & 0.54 & 2.4 & 1.01 & 1.91 \\
\hline Theta_r & 0.0679 & 0.055 & 0.0833 & 0.0655 \\
\hline Theta_sat VFS & 0.458 & 0.478 & 0.456 & 0.49487 \\
\hline Ksat VFS (cm/day) & 23 & 98.626 & 49.487 & 53.934 \\
\hline
\end{tabular}






Figure 1

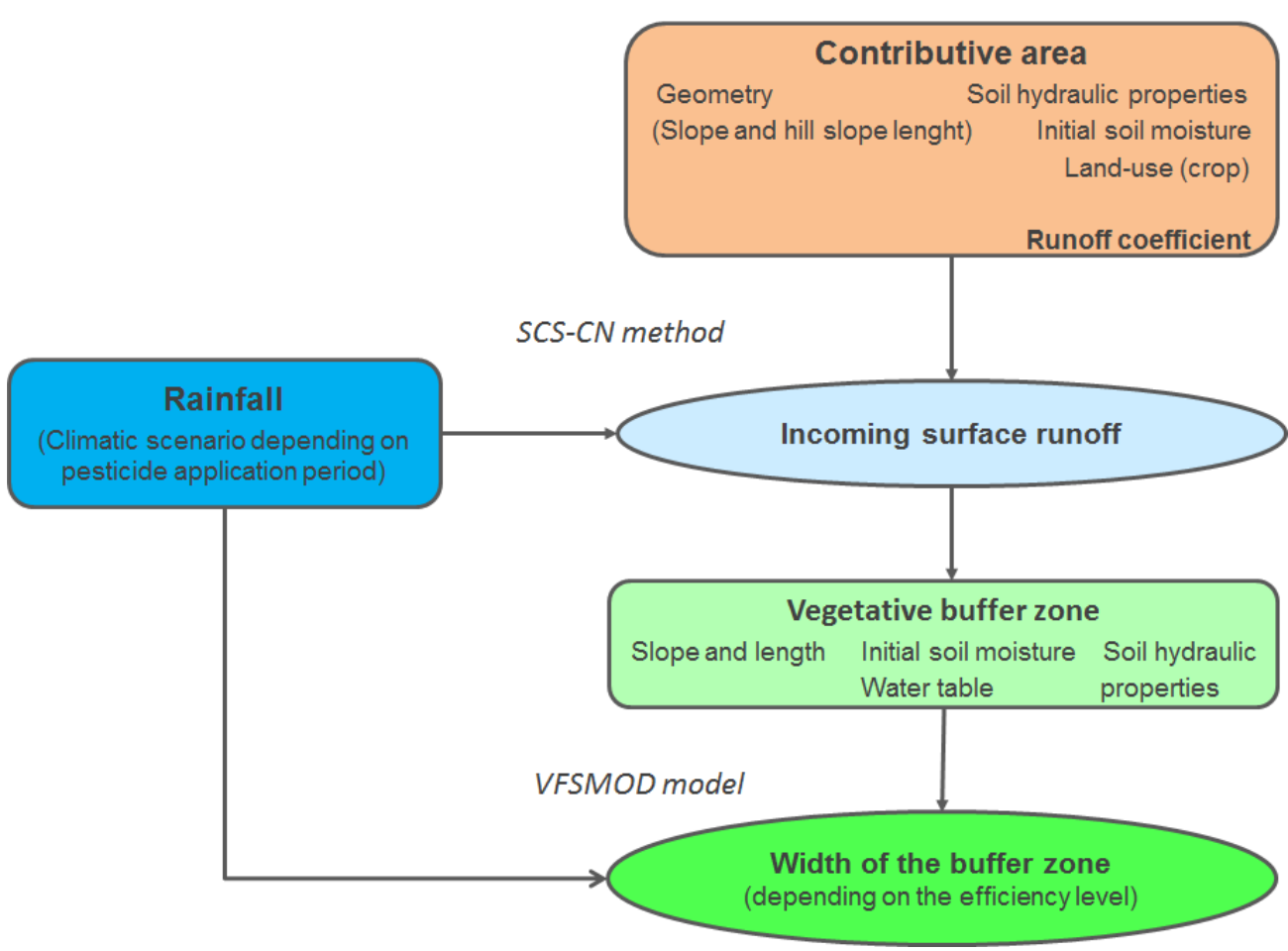

Figure 2 

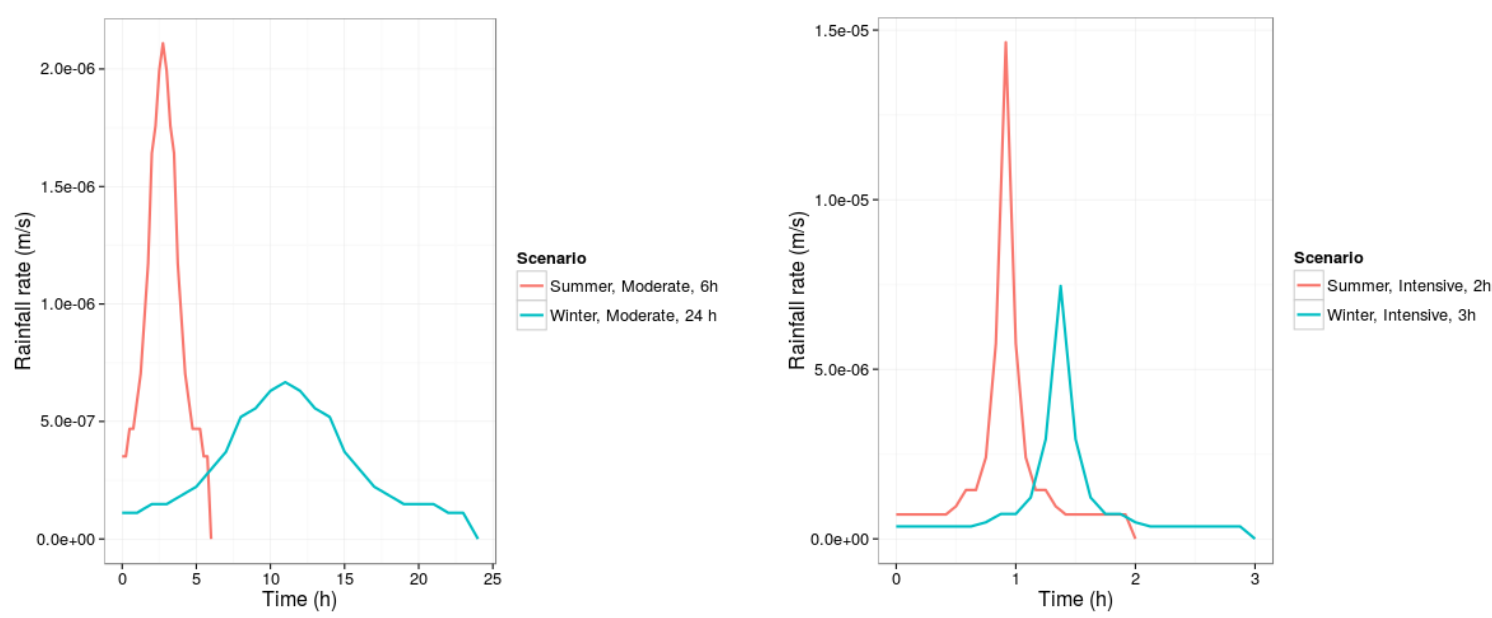

631

Figure 3

633

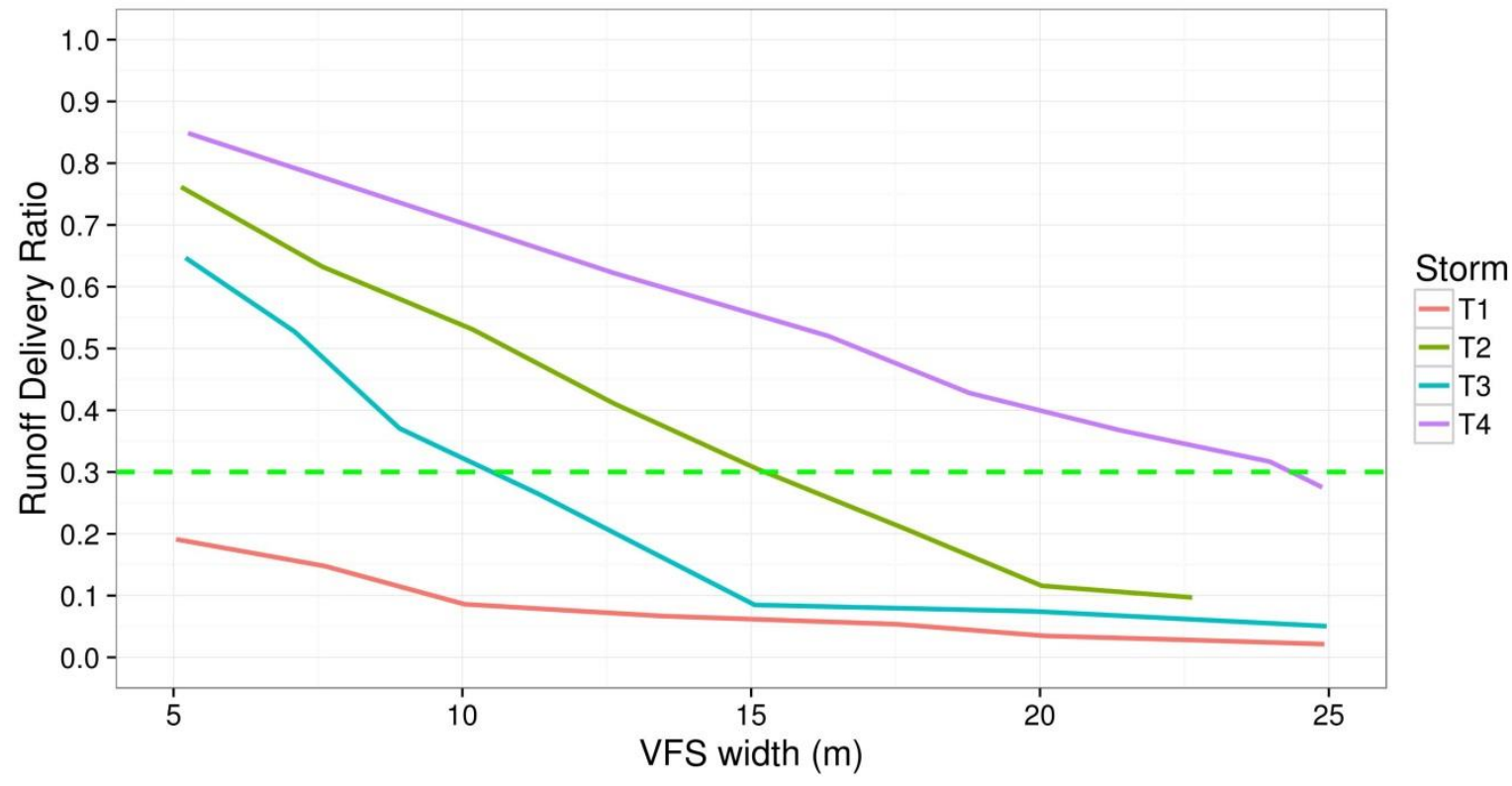

Figure 4 
Author-produced version of the article published in Science of The Total Environment, Volume 575, 1 January 2017, Pages 701-712

The original publication is available at http://www.sciencedirect.com/ http://dx.doi.org/10.1016/j.scitotenv.2016.09.105 This manuscript version is made available under the CC-BY-NC-ND 4.0 license

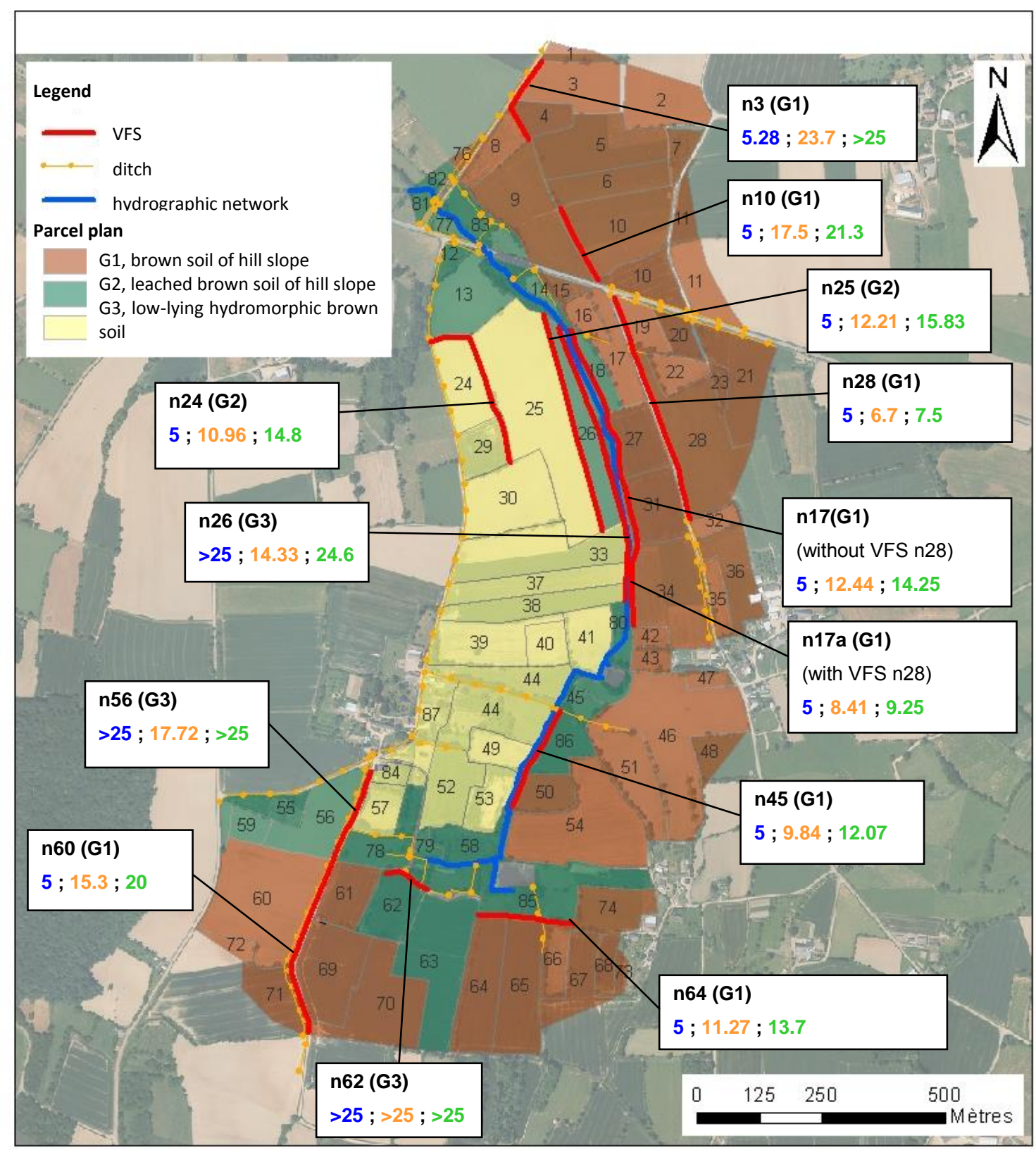

Figure 5
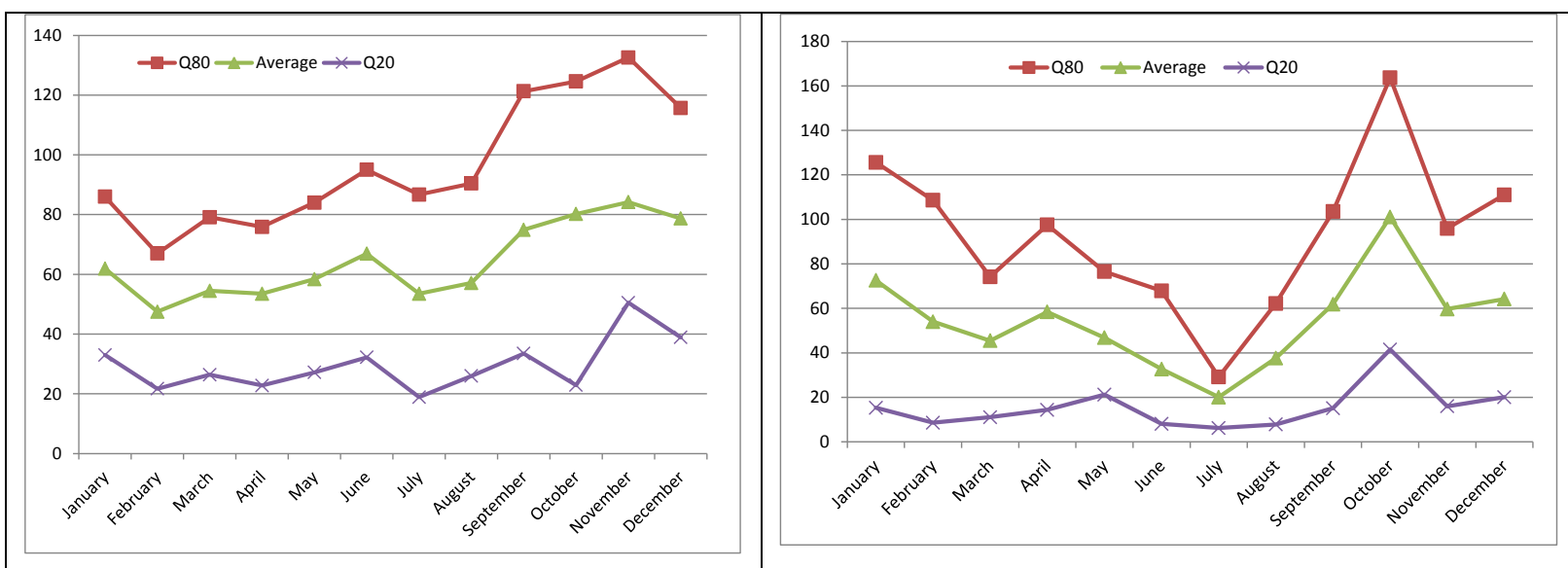




Figure 7 